10 years ESJ

Special edition

\title{
Digitalization and Digital Transformation and Adoption in the Public Administration during the Covid19 Pandemic Crisis
}

\author{
Dr. Panagiota Xanthopoulou \\ Visiting Researcher, Department of Political Science and International \\ Relations, University of Peloponnese, Greece \\ Dr. Sifis Plimakis \\ Assistant Professor, Department of Political Science and International \\ Relations, University of Peloponnese, Greece
}

Doi: $10.19044 /$ esj.2021.v17n31p60

Submitted: 29 April 2021

Accepted: 12 July 2021

Published: 15 September 2021
Copyright 2021 Author(s)

Under Creative Commons BY-NC-ND

4.0 OPEN ACCESS

Academic Editors: Georgios Farantos \& Nikitas-Spiros Koutsoukis

Cite As:

Xanthopoulou P. \& Plimakis S. (2021). Digitalization and Digital Transformation and Adoption in the Public Administration during the Covid19 Pandemic Crisis. European Scientific Journal, ESJ, 17 (31), 60. https://doi.org/10.19044/esj.2021.v17n31p60

\begin{abstract}
The objective of the study is to find the key organizational factors that impact on digital transformation projects, creating thus a social value especially during the current pandemic crisis where many changes have been made in the ways that organizations operate. An interdisciplinary approach was used and comparison among selected European Union countries where digital governance has been applied to public-to-citizen transactions. A quantitative survey was also conducted by distributing online questionnaires to middle and senior executives of public organizations in Greece. A total of 151 questionnaires were answered and their analysis was performed using the SPSS statistical tool. The results showed that the internal factors that influence the adoption of digital governance and its successful implementation include the technological factors that compose the quality of services and mainly the organizational ones such as training and evaluation of human resources, leadership, organizational strategy, and the creation of digital culture.
\end{abstract}


Keywords: Digitalization, Digital Transformation, Public Sector, Organizational Factors

\section{Introduction}

Implementing organizational changes is a difficult task, because although important steps have been taken towards their effective management, change programs continue to show high failure rates. Therefore, more research suggests a focus on the typical features of a successful public and private sector change program, which indicates that there is still a need for conceptual research of the field. It is also verified that most of the empirical research on digital governance and digital transformation of the public sector was qualitative using case studies, which cannot lead to generalization prospects, only to theoretical ones, and therefore it would be useful to invest in quantitative research methods in order to allow the results to be generalized. Consequently, there is also a great lack of mixed studies and, therefore, it would be more valuable to draw more attention to this. Mixed studies allow researchers or a team of researchers to combine elements of qualitative and quantitative research approaches for a broader purpose of breadth and depth of understanding and confirmation according to Schoonenboom \& Johnson (2017).

Digital transformation in the public sector means new ways of working with stakeholders, creating new service delivery frameworks and new forms of relationships (European Commission, 2013). However, there is little systematic empirical evidence on how public administrations currently define digital transformation in their day-to-day practices, how they approach digital transformation projects, and what the expected results are (Eggers \& Bellman, 2015). In fact, terms such as digitization, digitalization, digital governance or digital transformation are used interchangeably in the literature. Second, executives need to create a climate of empowerment and continuous improvement of digital skills and, finally, align all employees with a common vision around digital transformation. It is important for leaders to understand the digital transformation and to show a willingness to take these changes into account. Leadership seems to have a direct impact on digital maturity itself (Danailova, 2014; Xanthopoulou \& Karampelas, 2020). Civil servants are those employees who serve the public interest through their performance (Gerxhi, 2015) thus ensuring success in the digitization of the public sector requires strong central support and leadership complemented by preventive local and regional initiatives promoted by local actors (Millard, 2010). Digital technologies alone provide little value to an organization (Kane et al., 2015). It is their use in a specific context that enables a company or organization to discover new ways of creating value, according to the enduring idea that organizational change is an emerging phenomenon (Markus \& Robey, 1988). 
The literature emphasizes change as well as redefining business models (Osterwalder \& Pigneur, 2010) in the context of digital transformation (e.g. Morakanyane et al., Piccinini et al., 2015b). The success of e-governance and digital governance systems also depends significantly on how citizens perceive the value achieved by using these systems (Scott et al., 2016).

The present study aims to investigate those factors that affect the results and the successful adoption of the digital transformation. More specifically, it examines the key success factors associated with digital transformation projects and sets out a proposed framework for creating social value to society. Our results can be useful for policymakers considering the implementation of similar systems in their public administration and management decisions. The digital transformation in the form of substantially new organizational practices, skills and models has become the key theme in modern public administrations and management processes. However, despite growing need for digital transformation in the public sector, current research has rarely focused on adopting specific technologies (from social media to block chain) and processes (from digitized transactions to flexible contracts). As a result, we still know relatively little about whether and how the adoption of digital technologies is associated with real transformations of entire public sector organizations, with the emergence of new public administration and policy practices, and, ultimately, with new public sector reforms. The originality and contribution of the current research lies in the fact that there is little systematic empirical evidence on how public administrations currently define digital transformation in their day-to-day practices, with the majority of research using only qualitative research methods and focusing on mainly technological components. Our results can be useful for policy makers considering the implementation of similar systems in their public administration practices.

From the above, we can conclude to the following research question:

1. What are the key success factors for digital transformation projects in public organizations?

\section{Bibliographic Review}

\subsection{Digitalization and Digital Transformation}

Many researchers have defined digitalization in different perspectives. Kaplan et al. (2004) refer to the changes associated with the application of digital technology in all aspects of human society. Arnold and Wade, (2015) describe digitalization as something "paperless" and as the application of the digital tools to all aspects of society. Jurisic \& Kermek (2011) observe that almost all sectors are affected by digitalization. First, it is important to make a first distinction between the terms "digitization" and "digitalization" which are used as synonyms. The "digitization" refers to the conversion of 
information from something analog to a digital one (Picard, 2011) or to the automation of processes through information communication technologies (Hess et al., 2016) (for example, scanning a document or typing handwritten notes in an excel file). On the other hand, as Imgrund et al. (2018) state, "digitalization" means significant improvements in the use of information technology by organizations, the implementation of information technology strategies and information processing capabilities. Thus, if digitization refers to the conversion of data and processes, digitalization refers to a transformation and embraces the ability of digital technology to collect data, establish trends and make better business decisions. The same conclusion comes from Gartner Group (2016) for which digitalization involves the use of digital technologies to change business models, provide new revenue and value creation opportunities. Similarly, according to Legner et al. (2017), digitalization is understood as the socio-technical process of adaptation of new digital technologies, or a process of adaptation of digital technologies that occur at the individual, organizational, social and global level.

Digitalization, as a socio-technical phenomenon of adjusting digital technologies, "disrupts" markets and organizations (Legner et al., 2017) and makes them flexible and competitive within the rapidly changing market conditions (Berghaus \& Back, 2017; Fitzgerald et al., 2013). To overcome this challenge, organizations are responding to their digital transformation, they create digital transformation strategies that seek to transform their activities and processes (Chanias \& Hess, 2016; Matt et al., 2015; Porter and Heppelmann, 2014) and to adapt their internal configuration to digital innovation (Duerr et al., 2018; Westerman and Bonnet, 2005; Yoo, 2010; Xanthopoulou, 2021). In addition, digitalization is defined as the process of using technologies to change a business model in order to increase opportunities for higher revenue and value-added activities. Digitalization, as mentioned above, is implemented through the use of Information and Communication Technologies (ICT) and Information Systems (IS) in various industries (Gartner, 2016). The first focused definition was introduced by Maxwell and McCain (1997), who considered digitalization as the conversion of analog signals to digital ones, focusing exclusively on the technology factor. Subsequently, the above description was supported by Hagberg et al. (2016), Parviainen et al. (2017) and Eling \& Lehmann (2018), while Machekhina (2017) described digitalization in a broader way, characterizing it as types of information in digital language.

In relation to e-government, digitalization involves the transformation of traditional, bureaucratic and "paper-based" processes into digital platforms (Janssen \& Estevez, 2013). In this context, digitalization is seen as the advanced form of e-government innovation that redesigns natural processes to promote efficiency and effectiveness (Irani et al., 2008; Weerakkody et al., 
2011). It contributes to the promotion of democracy, transparency, accountability and freedom (Falk et al., 2017) and it also offers opportunities for governments to modernize public administration and cooperation with citizens and businesses (Falk et al., 2017). One form of public sector modernization is the simplification of procedures through the standardization of activities to increase efficiency and reduce response time (Calvo \& Campos, 2017). At the same time, digitalization leads to cost savings in public administration (Falk et al., 2017; Davison et al., 2005; Grönlund \& Horan, 2004; Venkatesh et al., 2012). In general, digitalization helps to streamline costly and inefficient vertical and horizontal processes (Janowski, 2015; Janssen \& Estevez, 2013; Sun et al., 2020).

Digital governance according to Luciano et al. (2018) is the way that governments use ICT to provide information and government services to citizens, to improve the quality of ICT services and to provide greater opportunities for citizen participation. It includes a new leadership style and a new way of making public policy and investment decisions (Kalsi \& Kiran, 2015). Thus, digital governance has evolved as a governance model that enhances the potential of the public sector to use appropriate technologies for improving governance relations - both internal and external - at various levels of government. Its objectives are to promote democracy, the right to expression and human dignity, to support economic development and to encourage the effective and efficient provision of services to society (Saxena, 2005). Digital governance refers to the use of ICT to create public value through the cooperation of society and the provision of appropriate information and citizen participation (Kalsi \& Kiran, 2015; Dawes, 2008).

From the late 1970's, traditional public administration was criticized because it did not meet the needs of developing and changing the new world (Karasoy, 2018). E-government focuses on the administration and management within an organization, public or private, and it refers to the internal use of ICT (especially the Internet) for horizontal and multilevel management of organizational resources, policy and process management in order to ensure accountable, transparent, effective, and efficient services. Digital governance, on the other hand, can be described as a stage of egovernment maturity and refers to the digital transformation required for a collaborative government / administration model, more citizen-centered that creates social, public value (Xanthopoulou, 2020). Figure 1 shows the transition from the traditional bureaucratic public administration to the creation of social value. 
Figure 1: From traditional public administration to the creation of public value

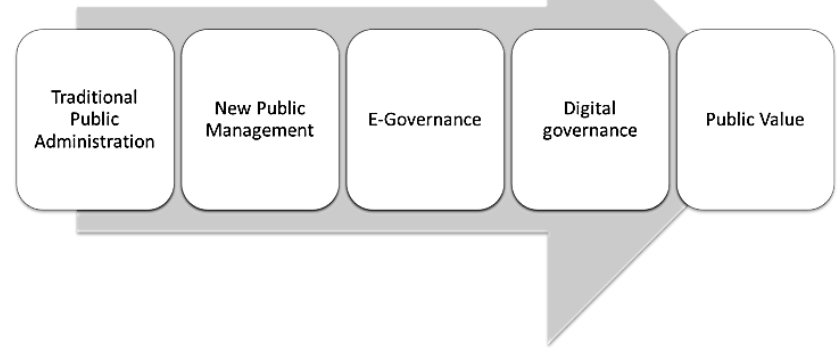

\subsection{Factors influencing the success of digitization projects}

Public sector digital projects are integrated into combinations of policy reforms and organizational changes designed to establish, support, and promote transformation in public organizations (Cordella \& Iannacci, 2010). Many digital projects in the public sector fail and the expectations are not met due to the inability to deal with complexity and uncertainty. Although digital transformation is a more pressing issue than ever, this does not mean that the process is less demanding especially in the public sector. The unique issues that arise from the pandemic crisis add to some common obstacles to an effective digital transformation and to a further value creation to citizens, which generally include:

- Lack of clear vision for digital transformation

- Resistance to change

- Ineffective data- rigid development technologies and processes

- Old systems that hinder digital progress

- Lack of alignment and clear understanding among leaders on how to execute a digital transformation strategy

- Lack of commitment and sponsorship of top management

- Concerns from top management that their organization's digital transformation project is a waste of time

- Fear of the overall complexity of the initiative and the uncertainty of its success

- Insufficient understanding of how employees and customers are evolving, especially in a pandemic period like the current one

- Perception that the digital transformation and governance initiative belongs to or is driven exclusively by technology and information technology

The use of technology in the public sector requires organizational change and the realization that productivity presupposes fundamental 
exploitation of opportunities through a transition to fully digital functions (Dunleavy et al., 2006). Dynamic competence, leadership transformation, interpersonal skills, entrepreneurship and governance skills are key characteristics of successful transformation projects (Lewis, 2017). Organizations need to establish governance processes at management level to succeed in their digital transformation (Matt et al., 2015). Many studies have attempted to analyze the digital transformation's barriers from a variety of perspectives. Others focus on internal characteristics of organizations, others on stakeholders and those involved in digitization projects, and still others on external factors, while many of them follow a combination way of thinking. The findings of Effah \& Nuhu (2017) show that outdated laws and culture are institutional barriers to digitalization. Other barriers included not using an integrated system approach as well as insufficient and unreliable internet access for all participating units.

Despite the benefits of digitalization, its development in the public sector can be a challenge (Falk et al., 2017). In general, the nature of culture and structures / organization in the public sector can be barriers to digital innovation (Heeks \& Stanforth, 2007; Irani et al., 2007; Weerakkody et al., 2011). The traditional public sector in mainly western countries is characterized by hierarchical and dissimilar structures, as well as bureaucracy and procedures based on print media (Davison et al., 2005; West, 2004) that cause deficiencies and delays (Beynon-Davies, 2007). Initially, the bureaucracy with its literal interpretation (office administration) in the public sector was initially aimed at promoting efficiency, equality and democracy (Cordella \& Iannacci, 2010). Today, however, it has become a source of multiplier and recurring delays and inefficiencies (Davison et al., 2005; Wiredu, 2012). Other problems arising from the structure and culture of the public sector include functional divisions and politics (Beynon-Davies, 2007; Irani et al., 2007) as well as resistance to innovation (Seng et al., 2010; Zhao \& Khan, 2013). The lack of exchange of information between departments and organizations also poses challenges to digitalization (Davison et al., 2005). Resistance by civil servants for fear of job loss (Falk et al., 2017) also limits digitalization in the public sector. Barriers identified by international research include complex and multi-layered bureaucratic structures inherited from previous forms and schools of administration (Imran, 2013), e-literacy and inadequate ICT infrastructure (Bertot et al., 2010; Heeks \& Stanforth, 2007; Hendrix, 2013). Other challenges include resistance to change, power struggles and lack of cooperation between organizations (Schuppan, 2009), as well as failure to update existing laws (Basu, 2004).

Nevertheless, research focusing specifically on the institutional barriers to the reintegration of e-government and d-government in developing countries remains limited. One of the first approaches to identifying barriers 
is that of Piatier (1984), which gave rise to barriers to the approach to innovation. Different classifications of barriers have appeared in the literature. Often, these are differentiated into internal and external barriers, which are further subdivided. Specifically, internal barriers include challenges related to resources, management systems, time, organizational culture and systems, as well as challenges related to the human factor. External barriers are subdivided in relation to supply, demand and the environment (Hadjimanolis, 2003). The classification between internal and external environments has been shown to be useful in many studies in different contexts (Demirbas et al., 2011; Madrid - Guijarro et al., 2009). D'Este et al. (2012) report a differentiation in reporting barriers describing the innovation process and deterrent barriers corresponding to barriers to adopting an innovation. A study by Coad et al. (2016) listed four different barriers such as the cost, the knowledge, the market and the regulatory framework. Another differentiation has been noted in factors related to projects, products and the market (Van der Panne et al., 2003).

Many studies have conceptually and empirically examined the challenges and barriers to the adoption of technology in public administrations. According to Fountain (2004), how a technology is applied depends on the institutional and organizational arrangements that guide decision makers in their day-to-day behaviors. The model of Fountain (2004) is commonly used to describe the interactions between organizational forms and institutional arrangements and their implications for the design of a technological system (Cordella \& Iannacci, 2010; Luna-Reyes \& Gil-Garcia, 2014). Both factors - organizational forms and institutional arrangements may hinder the adoption of new technologies in the public sector. For example, Salvoldelli et al (2014) showed that institutional arrangements have prevented the adoption of e-government solutions in the European Union. Conradie \& Choenni (2014) showed similar results for open data in the Netherlands on organizational factors. Thus, the acceptance of technologies depends to a large extent on their compatibility with existing institutional and organizational arrangements. Empirical analysis of barriers to the application of ICT in the public sector have focused mainly on e-government - from a technological point of view, a previous public sector innovation. Numerous empirical studies have found barriers to the adoption of e-government, including a lack of trust (Gilbert et al., 2004), general concerns about public safety, privacy and data protection (Schwester, 2009; Wing, 2005; Zakareya \& Zahir, 2005), information quality (Gilbert et al., 2004), strategy (Wing, 2005; Zakareya \& Zahir, 2005), technology (Schwester, 2009; Lam, 2005; Zakareya \& Zahir, 2005), policy (Lam, 2005), leadership and management (Kim et al., 2009; Schedler \& Schmidt, 2004; Schwester, 2009), accessibility (Becker, 2004; Gilbert et al., 2004) and organizational weaknesses (Chen \& Gant, 2001; Schwester, 2009; Lam, 2005; Zakareya \& Zahir, 2005). 
In their meta-analysis, Savoldelli et al. (2014) identified three groups of barriers to the adoption of e-government: technological and economic, managerial and organizational, and institutional and political. While digital transformation research emphasizes the need for an adequate "digital culture", that is, an organizational culture suitable for successful digital transformation (Hartl \& Hess, 2017), the majority of studies only touch on the subject of culture and specific features of change in the context of digital transformation or appropriate approaches to its management. Technological factors cited in the literature as barriers to these transformation efforts include system complexity and incompatibility (Gil-Garcia et al., 2007) as well as lack of business architecture (Janssen \& van Veenstra, 2005; Kamal et al., 2009), standards and interoperable systems (Ebrahim \& Irani, 2005). In addition, security threats are identified as barriers (Ebrahim \& Irani, 2005).

\subsection{Digitalization during the pandemic crisis of Covid-19}

Digital transformation has emerged as a condition in the last decade, with the aim of redesigning public and private sector services to improve the daily work of employees and civil servants, while effectively meeting the needs of citizens (Karamalis \& Vasilopoulos, 2020). However, the COVID19 pandemic crisis has caused many problems, not only in public health, but also in public sector organizations worldwide. Greece had to take significant and rapid steps towards the digitalization of many of its businesses both to protect citizens from the pandemic consequences and to provide services more efficiently and in a timely manner.

Although there are many studies that discuss the potential in the private sector (Teece, 2017; Helfat \& Martin, 2015; Xanthopoulou \& Kefis, 2019), only a few studies examine the dynamics and innovation in the public sector. Breznitz (2007) and Block (2008) report that there are many public bodies and agencies, and even entire countries that manage to change the way they work and provide quality services to citizens. Similarly, Janssen et al. (2012) report that e-government is an area of growing interest for public sector executives through Open Government Data (OGD), as it allows government agencies to communicate to the public the data they collect in an accessible, comprehensible and redistributable way. The OECD in its latest report states that Greece ranks very well (9th), ranking it above the OECD average (Figure 2) and countries such as Germany, Italy, the United Kingdom and Norway among others (OECD Government at a glance, 2019). Heeks (2006) highlights three important contributions of e-government, namely the process of government, connecting citizens and creating external interactions by studying case studies from Chile, South Korea, Honduras and the Philippines. 
Figure 2: Digital public services (DESI Score)

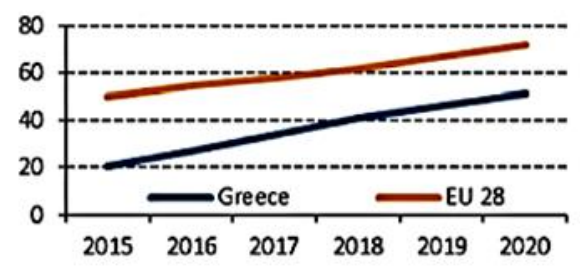

Source: DESI 2020

The COVID-19 is a huge challenge for governments around the world - from providing income support to citizens and business assistance to strengthening first-line health services. It also requires an unprecedented level of cooperation between nations. One of the biggest lessons is that the state's ability to manage a crisis of this magnitude depends on the cumulative investment it has made in its ability to govern, implement and manage. While the crisis is serious for all, it is particularly challenging for countries that have ignored these necessary investments in "dynamic public sector potential" (Kattel \& Mazzucato, 2018). Prior to COVID-19, governments are increasingly focusing on how to address "major challenges" or issues such as climate change, demographic challenges, and the promotion of health and wellness (Mazzucato \& Quaggiotto, 2020). Behind these challenges are the difficulties of creating sustainable and inclusive growth. Policymakers have increasingly turned their attention not only to the pace of economic growth, but also to its direction (Mazzucato \& Perez, 2015; Lazonick \& Mazzucato, 2013). COVID-19 is a huge test of governments' ability to manage societies in crisis (Gaspar et al., 2020). The crisis has disproportionately affected some countries due to varying degrees of preparation, perspective and the ability of the public sector to direct economic activity. Countries such as the US and the $\mathrm{UK}$, in particular, have realized how vulnerable their production and public health systems are and how difficult it is to increase production and coordinate supply chains for food, medicine, respirators, and protective equipment. In these economies, the pandemic has highlighted the damage caused by administrative reforms in the public sector, such as outsourcing and financing of the economy, to the resilience of socio-economic systems. Other countries, such as Germany and South Korea, have shown much greater resilience in their production and health systems, thanks to their governments' ability to coordinate with the private sector and, to public ownership of critical elements of the health system (Chazan, 2020; Bouckaert et al., 2020). There are also cases of success in emerging markets. In India, Kerala's successful response to the crisis is also the result of long-term health investments (including protocols implemented after the Nipah outbreak) and a successful publicprivate partnership model (Mazzucato \& Quaggiotto, 2020). In Vietnam, the 
government quickly recognized the complexity of the problem, closed its borders early, and rapidly pushed for the development of low-cost test kits (Klingler-Vidra et al., 2020). Eastern European countries quickly imitated successful crisis management practices from Southeast Asia and quickly closed borders, closed large sections of public activity and often made masks mandatory for the public (Shotter \& Jones, 2020).

During pandemics, governments must respond to emergencies by organizing rapid response and mobilizing resources. Effective governance requires skills and abilities for both flexibility and resilience (Drechsler \& Kattel, 2020). Public sector capacity is usually defined as the set of capabilities and resources required to perform policy functions, from public service delivery to policy planning and implementation (Wu et al., 2018). The potential of the public sector shows that existing frameworks focus on external sources (Piening, 2013). Similarly, the business approach to strategy and leadership in public sector organizations tends to focus on the importance of individual leaders and teams in adopting strategic initiatives. Thus, public sector-related competencies tend to be narrow and focus on stability (i.e. continuity, transparency, predictability of services).

While responses to COVID-19 have shown how vital both long-term and short-term public sector capacity and capabilities are, the last half century has been marked by declining governments' ability to adapt and learn (Mazzucato \& Kattel, 2020). In addition, public services have been a frequent target of reforms, particularly in healthcare, as they are often a large public sector cost-cutting sector, with some similarities to private services, e.g. production of individual services and a certain field for standardization and quantitative monitoring of production. However, there is no evidence that such reforms have led to improved results (Simonet, 2011). Instead, they have led to a more transactional view of public services that focuses on the ease and efficiency of service delivery rather than meeting essential needs or developing human skills (Cottam, 2018). Another need is undoubtedly the ability to manage data and digital platforms. NPM reforms have led many governments to outsource their functions, which have had a detrimental effect on governments' digital capabilities. Comparing a number of countries, Dunleavy et al. (2006) found that countries with the most enthusiastic absorption of NPM had very poor exploitation in digitization, with the United Kingdom emerging as a world leader in inefficient government IT systems. Trusting the potential of the public sector and bringing new contractual risks and obstacles to intergovernmental policy-making, the NPM has drastically influenced the modernization of government IT. Furthermore, in order to rebuild the capacity of the public sector after COVID-19, the public sector must be seen from a new perspective. Investing in long-term skills and competencies in public organizations provides sources of flexibility and 
responsiveness during deep crises and their consequences. It is no coincidence that another pandemic success story comes from New Zealand, a country that in the 1980s had fully embraced the new system of external government, only to change course and begin a period of power-sharing (Warner, 2008). Perhaps unsurprisingly, early June 2020 also became the first country in the world to get rid of COVID-19.

Based on the findings of the literature review, the following conceptual model was used in the present research process and it is presented in Figure 3 below.

Figure 3: The conceptual model of research

Organisation

- Organizational culture

- Organizational weaknesses

- Adherence to traditional public administration

- Bureaucratic organization of public administration - Human resources

- Resistance to change

- Lack of Incentives for change and innovation

- Lack of technical skills

Planning

- Lack of a comprehensive digital transformation strategy

- Resources: skills, materials, equipment

\section{Leadership}

- Lack of common vision

- Governance skills

- Interpersonal skills and communication

- Knowledge and information management

- Climate of non-cooperation

\section{Control}

- Lack of commonly accepted indicators-criteria for measuring the success of digital governance
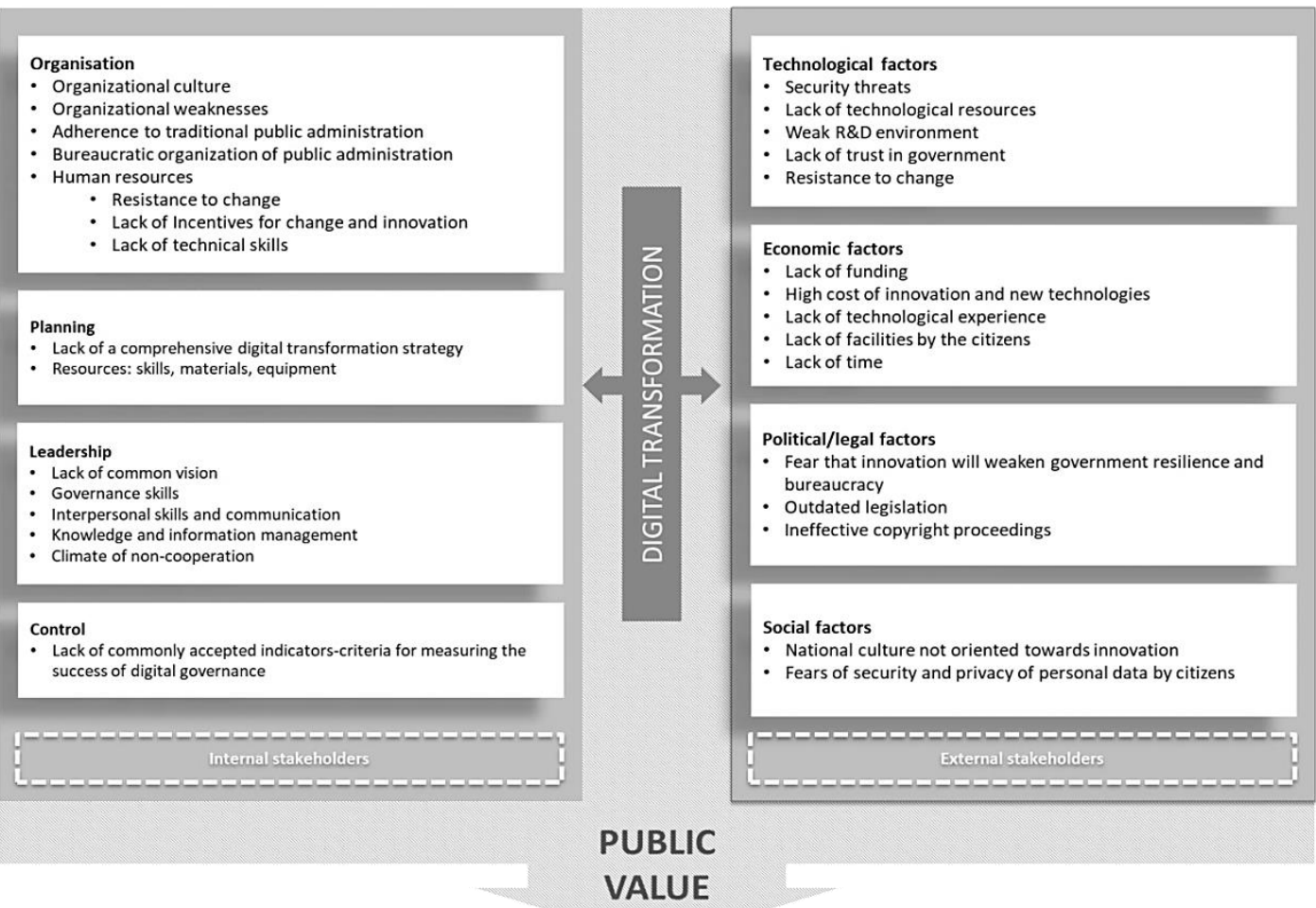

\section{Methods}

\subsection{Quantitative survey}

The types for a survey are both quantitative and qualitative. These two researches differ in the philosophical assumptions about the nature of the phenomena to be studied, in the research objectives, in the research tools used, in the data collection method, and in the means of data analysis (Balnaves \& Caputi, 2001). In the present research it was chosen to distribute questionnaires to middle and senior executives of public organizations, so to conduct a quantitative survey, to executives of public organizations that use these digital services in Greece in order to evaluate the effectiveness and 
efficiency of this digital project (value based approach) and mainly to reveal the internal organizational factors that affect them. The analysis of the quantitative data derived from the questionnaires was carried out using statistics (SPSS) with the aim of better organizing and recording them.

In order to measure the components that influence the success of digital adoption by public organizations, a 39-item questionnaire was distributed, a research tool that had previously been tested and validated in other studies (e.g. Abhichandani et al., 2005; Morgeson et al., 2011; Park and Blenkinsopp, 2011; Parasuraman et al., 1988; Mahmood, 2018; Al Hujran, Aloudat \& Altarawneh, 2013). In total, 151 questionnaires were answered and as mentioned, the participants were middle and senior executives in public organizations, during the lockdown period from October 2020 to March 2021. This sample allows us to proceed with reasonable and reliable statistical analyzes and to draw valid conclusions. In addition, the validity of the questionnaire is ensured by the synthesis of questions of already published questionnaires in international surveys but also by the use of the findings of the literature. The study examined the relationships between these components: Service Quality, Information Quality, and Perceived Impact on the organization and the dependent variable that is the Degree of Adoption $(D A)$ of digital governance in a public organization with SOAL. Component analysis is used to reduce the number of variables to fewer component numbers, with three ultimately retained (Service Quality (SQ), the second is Information Quality (IQ) and the last is the Perceived Impact (PI) on the organization). The Cronbach Alpha reliability test was used to measure the reliability of each component. The data were analyzed using the multiple regression routine of SPSS software version 24.

\section{Research results}

The total sample of the study consisted of $\mathrm{N}=151$ respondents, 109 (72.2\%) were women and $42(27.8 \%)$ were men. The structure of the observed correlations was determined from Table 1 of the component analysis method, identifying the groups of variables that have a high correlation. As shown in Table 1 below, the first component is Service Quality (SQ), the second is Information Quality (IQ) and the last is the Perceived Impact (PI) on the organization. Table 2 with KMO and Bartlett's Test shows that the date from the sample were adequate for the components analysis $(\mathrm{KMO}=0,803>0,60$, Bartlett's Test significance <0,001) (Yong, 2013; Kinnear \& Gray, 2011). 
Table 1. Rotated Component Matrix ${ }^{\mathrm{a}}$

\begin{tabular}{|c|c|c|c|}
\hline \multicolumn{4}{|c|}{ Rotated Component Matrix ${ }^{a}$} \\
\hline & \multicolumn{3}{|c|}{ Component } \\
\hline & 1 & 2 & 3 \\
\hline SQV2 & 0,71 & 0,00 & 0,00 \\
\hline SQV3 & 0,59 & 0,00 & 0,00 \\
\hline SQV6 & 0,66 & 0,00 & 0,00 \\
\hline SQV7 & 0,69 & 0,00 & 0,00 \\
\hline SQV8 & 0,66 & 0,00 & 0,00 \\
\hline SQV9 & 0,68 & 0,00 & 0,00 \\
\hline IQV10 & 0,00 & 0,73 & 0,00 \\
\hline IQV11 & 0,00 & 0,75 & 0,00 \\
\hline IQV13 & 0,00 & 0,59 & 0,00 \\
\hline PIV23 & 0,00 & 0,00 & 0,67 \\
\hline PIV25 & 0,00 & 0,00 & 0,75 \\
\hline PIV26 & 0,00 & 0,00 & 0,78 \\
\hline PIV28 & 0,00 & 0,00 & 0,56 \\
\hline PIV30 & 0,00 & 0,00 & 0,78 \\
\hline
\end{tabular}

Extraction Method: Principal Component

a. Rotation converged in 5 iterations.

Table 2. KMO and Bartlett's Test

\begin{tabular}{|l|l|r|}
\hline \multicolumn{3}{|c|}{ KMO and Bartlett's Test } \\
\hline Kaiser-Meyer-Olkin & 0,83 \\
\hline Bartlett's & Approx. & \\
Test of & Chi- & 614,754 \\
Sphericity & Square & \\
\cline { 2 - 3 } & df & 91,00 \\
\cline { 2 - 3 } & Sig. & 0,00 \\
\hline
\end{tabular}

Next, a reliability test Cronbach's alpha interpreted for the questions of each component. The results showed that the alpha coefficient for the first component (Service Quality- SQ) is 0.79, for the second (Information QualityIQ) is 0.62 , and for the third (Perceived Impact-PI) is 0.77. In most cases a reliability factor of 0.7 or higher is acceptable in social science research. The alpha coefficient for the second component (Quality Information) is $0.62<0.7$ which means that the data do not have high internal consistency (Kinnear \& Gray, 201; Baglin, 2014).

Table 3. Cronbach's Alpha

\begin{tabular}{|c|r|l|r|r|r|r|r|}
\hline \multicolumn{2}{|c|}{ SQ } & & \multicolumn{2}{c|}{ IQ } & & \multicolumn{2}{c|}{ PI } \\
\hline $\begin{array}{c}\text { Cronbach's } \\
\text { Alpha }\end{array}$ & N of Items & & $\begin{array}{c}\text { Cronbach's } \\
\text { Alpha }\end{array}$ & N of Items & & $\begin{array}{c}\text { Cronbach's } \\
\text { Alpha }\end{array}$ & N of Items \\
\hline 0,79 & 6,00 & & 0,62 & 3,00 & & 0,77 & 5,00 \\
\hline
\end{tabular}


Table 4. Statistics

\begin{tabular}{|c|c|c|c|c|c|}
\hline \multicolumn{6}{|c|}{ Statistics } \\
\hline & & $S Q$ & $\mathrm{IQ}$ & $\mathrm{PI}$ & $\mathrm{DA}$ \\
\hline \multirow[t]{2}{*}{$\mathrm{N}$} & Valid & 151,00 & 151,00 & 151,00 & 151,00 \\
\hline & Missing & 0,00 & 0,00 & 0,00 & 0,00 \\
\hline \multicolumn{2}{|c|}{ Mean } & 3,79 & 3,66 & 4,43 & 3,37 \\
\hline \multicolumn{2}{|c|}{ Median } & 3,83 & 3,67 & 4,60 & 4,00 \\
\hline \multicolumn{2}{|c|}{ Std. Deviation } & 0,54 & 0,57 & 0,51 & 1,05 \\
\hline \multicolumn{2}{|c|}{ Variance } & 0,29 & 0,32 & 0,26 & 1,11 \\
\hline \multicolumn{2}{|c|}{ Skewness } & $-1,23$ & $-0,05$ & $-1,02$ & $-0,69$ \\
\hline \multicolumn{2}{|c|}{ Kurtos is } & 3,63 & 1,18 & 1,36 & $-0,11$ \\
\hline \multicolumn{2}{|c|}{ Std. Error of Kurtosis } & 0,39 & 0,39 & 0,39 & 0,39 \\
\hline
\end{tabular}

The overall regression model was significant, the value of $\mathrm{R}^{\wedge} 2$ is greater than zero $(0,125)$. Table 5 shows the predictive power of the independent variables, in terms of the degree of adoption (DA) of digital governance in organizations. The value of $\mathrm{R}^{\wedge} 2$ is 0.125 which shows that the independent variables (Perceived Impact-PI, Information Quality-IQ and Service Quality-SQ) explain $12.5 \%$ of the variance of the dependent variable.

Table 5. Model Summary ${ }^{\mathrm{b}}$

\begin{tabular}{|l|r|r|r|r|r}
\hline \multicolumn{7}{|c}{ Model Summary } \\
\hline Model & R & R Square & $\begin{array}{c}\text { Adjusted } \\
\text { R Square }\end{array}$ & $\begin{array}{c}\text { Std. Error of the } \\
\text { Estimate }\end{array}$ & $\begin{array}{c}\text { Durbin- } \\
\text { Watson }\end{array}$ \\
\hline 1 &, $353^{\mathrm{a}}$ & 0,125 & 0,107 & 0,996 & 1,901 \\
\hline
\end{tabular}

a. Predictors: (Constant), $\mathrm{PI}, \mathrm{IQ}, \mathrm{SQ}$

b. Dependent Variable: DA

Table 6. ANOVA ${ }^{\mathrm{a}}$

\begin{tabular}{|c|c|c|c|c|c|c|}
\hline \multicolumn{7}{|c|}{ ANOVA $^{a}$} \\
\hline \multicolumn{2}{|l|}{ Model } & $\begin{array}{l}\text { Sum of } \\
\text { Squares }\end{array}$ & df & Mean Square & $\mathrm{F}$ & Sig. \\
\hline 1 & \begin{tabular}{|l|} 
Regressio \\
$n$
\end{tabular} & 20,82 & 3,00 & 6,94 & 6,99 & $0,000^{b}$ \\
\hline & \begin{tabular}{|l|} 
Residual \\
\end{tabular} & 145,91 & 147,00 & 0,99 & & \\
\hline & Total & 166,73 & 150,00 & & & \\
\hline
\end{tabular}

Table 7 shows the predictive ability of the three components, concerning the degree of adoption of digital governance. Quality of service (SQ), quality of information (IQ) and perceived impact (PI) are positively related to the adoption of digital governance in an organization. Service quality, information quality and perceived impact have a statistically significant effect on the outcome variable ( $\mathrm{p}$ value $<0,05$ ) (Yong and Pearce, 2013). 
Table 7. Coefficients ${ }^{\mathrm{a}}$

\begin{tabular}{|c|c|c|c|c|c|c|}
\hline \multicolumn{7}{|c|}{ Coefficients ${ }^{a}$} \\
\hline & & \multicolumn{2}{|c|}{$\begin{array}{l}\text { Unstandardized } \\
\text { Coefficients }\end{array}$} & \multirow{2}{*}{$\begin{array}{c}\begin{array}{c}\text { Standardized } \\
\text { Coefficients }\end{array} \\
\text { Beta }\end{array}$} & \multirow[b]{2}{*}{$t$} & \multirow[b]{2}{*}{ Sig. } \\
\hline \multicolumn{2}{|c|}{ Model } & $\mathrm{B}$ & Std. Error & & & \\
\hline \multirow[t]{2}{*}{1} & (Constant) & $-0,06$ & 0,81 & & $-0,07$ & 0,94 \\
\hline & $S Q$ & 0,47 & 0,17 & 0,24 & 2,68 & 0,01 \\
\hline & IQ & 0,17 & 0,17 & 0,09 & 1,04 & 0,30 \\
\hline & $\mathrm{PI}$ & 0,23 & 0,18 & 0,11 & 1,30 & 0,19 \\
\hline
\end{tabular}

The results presented above provide support for the findings of existing research and literature. The quality of services has a significant impact on the adoption of digital governance in a public organization and refers to concepts such as perceived ease of use, i.e. the degree to which the structure of the eservice portal is clear and easy for the user to navigate and is good aligned with the needs of individual users, it also addresses issues of availability and accessibility of the online service at any time and to the extent that the online service portal performs the service successfully at the request of citizens, operates quickly and facilitates everyday life and the online transactions of the users of the service with other companies / organizations.

Next, the quality of information also has an important relationship with the adoption of digital governance in a public organization. It refers to concepts found in international literature such as "trust and security" (for example, obtaining the username and password on the portal, transaction security in the online service, the availability of a data recovery plan, reliability and sequence of the GDPR, the privacy policy so that users have easy access to the respective service while browsing the site, the use of the site of digital signatures for the authentication of users, the monitoring of citizens' activity). In terms of content, an important role is played by monitoring the activity of citizens, the updating and accuracy of information displayed on the online services portal and finally the provision of web applications for a range of services (requests, payments, etc.).

Finally, the perceived impact on the organization also has a significant positive relationship with the adoption of digital governance in a public organization. In this component, important parameters related to the Equipment / Resources, the Policy / Strategy followed by the public organization as well as the Organizational culture and Leadership were examined.

\section{Conclusions and suggestions}

The aim of this research was to find the factors that influence the success of digital governance projects in the public sector. Initially, regarding 
the research question an extensive bibliographic review of international studies was carried out. Public sector is recently under pressure not only to develop new administrative reforms, but exclusively to match its priorities to the needs of citizens (Bala \& Koxhaj, 2017; Temizel, 2015). As mentioned, digitalization is today, especially in the current pandemic period of COVID19 the most important and continuous transformation of modern society in most areas of everyday life (Srai \& Lorentz, 2019); Ringenson et al., 2018; Valenduc \& Vendramin, 2017; Gebre-Mariam \& Bygstad, 2019; Eling \& Lehmann, 2018; Gobble, 2018).

In fact, terms such as digitization, digitalization, digital governance, or digital transformation are used interchangeably in the literature. In addition, it was found that the majority of them focus almost exclusively on the technological factors or, if reference is also made to organizational ones, the studies concerning the public sector are few in number. Through the research of these factors in the literature, a questionnaire was created whose axes initially corresponded to four components (Quality of service, Quality of information, Perceived Impact on the organization, Other - external factors). The results of the study showed that out of the four components, only three were statistically significant for the adoption of digital governance and in particular the importance of the first three was found. The answers demonstrated the importance of both the technological factors that compose the quality of service (Perceived ease of use, Promotion of digital governance and Perceived usefulness), the quality of information (Trust and security, Content) and the perceived utility in the organization (Equipment, Policy / Strategy, Organizational Culture and Leadership) as well as organizational factors, emphasizing the importance of training and evaluation of human resources in the successful adoption of digitalization but also the impact of leadership and top management in creating a digital culture within the organization. In the context of the adoption of digital governance, the support of top management plays an important role, because the adoption of new technologies may include new regulatory requirements, a high degree of complexity, new resources, resource integration, redesign and the development of new skills and competencies.

In general, the present study confirms the findings of the literature that the barriers and conditions for a successful transformation of digital government are not limited to technological issues. Many cases that arise suggest that the introduction and adoption of new technologies by governments is often hampered by organizational, institutional, and legal issues. This is often explained by the fact that new technologies are expected to challenge almost every process, system and structure of government. However, these changes are complex and require radical transformations. The aspect of transformation is often seen in the literature as the ultimate goal of 
the development of digital governance and implies the transition from the digitization of public services to wider government reforms. In order to sustain this transformation, there must be multiple processes of change and redesign, not only of the organizational processes involved, but also of regulatory and institutional aspects.

Finally, it is proposed that the current research topic be strengthened bibliographically but mainly empirically, collecting data from a larger number of public sector executives and from all levels of an organization. It is also proposed to enrich it with additional research on citizens who make use of digital governance and related services in order to have a more comprehensive picture regarding the creation of public value. Finally, referring to examples outside the European Union could provide more evidence to identify the factors that make up the success or hindrance of digital governance and transformation projects.

\section{References:}

1. Abhichandani, T., \& Horan, T. (2006). Toward a new evaluation model of e-government satisfaction: Results of structural equation modeling. AMCIS 2006 Proceedings, 35.

2. Al Hujran, O., Aloudat, A., \& Altarawneh, I. (2013). Factors influencing citizen adoption of e-government in developing countries: The case of Jordan. International Journal of Technology and Human Interaction (IJTHI), 9(2), 1-19.

3. Arnold, R. D., \& Wade, J. P. (2015). A definition of systems thinking: A systems approach. Procedia computer science, 44, 669-678.

4. Bala, A., \& Koxhaj, A. (2017). Key Performance Indicators (KPIs) in the Change Management of Public Administration. European Scientific Journal, ESJ, 13(4), 278. https://doi.org/10.19044/esj.2017.v13n4p278

5. Baglin J, (2014) Improving your exploratory factor analysis for ordinal data: A demonstration using FACTOR. Practical Assessment, Research, and Evaluation, 19(1), 5. doi: 10.7275/dsep-4220

6. Balnaves, M., \& Caputi, P. (2001). Introduction to quantitative research methods: An investigative approach. Sage.

7. Basu, S. (2004). E-Government and Developing Countries: An Overview. International Review of Law, Computers \& Technology, 18(1), 109-132.

8. Becker, S. A. (2004). E-government visual accessibility for older adult users. Social Science Computer Review, 22(1), 11-23.

9. Berghaus, S., \& Back, A. (2017, December). Disentangling the fuzzy front end of digital transformation: Activities and approaches. Association for Information Systems. 
10. Bertot, J. C., Jaeger, P. T., \& Grimes, J. M. (2010). Using ICTs to create a culture of transparency: E-government and social media as openness and anti-corruption tools for societies. Government information quarterly, 27(3), 264-271.

11. Beynon-Davies, P. (2007). Models for e-government. Transforming Government: people, process and policy.

12. Block, F. (2008). Swimming against the current: The rise of a hidden developmental state in the United States. Politics \& society, 36(2), 169-206.

13. Bouckaert, G., Galli, D., Kuhlmann, S., Reiter, R., \& Van Hecke, S. (2020). European coronationalism? A hot spot governing a pandemic crisis. Public Administration Review, 80(5), 765-773.

14. Breznitz, D. (2007). Innovation and the state: Political choice and strategies for growth in Israel, Taiwan, and Ireland. Yale University Press.

15. Calvo, A. S., \& Campos, C. (2017). Mexico: Single window for foreign trade. In Digital Government (pp. 85-103). Springer, Cham.

16. Chanias, S., \& Hess, T. (2016). Understanding Digital Transformation Strategy formation: Insights from Europe's Automotive Industry. PACIS, 296.

17. Chazan, G. (2020). Germany's oversupply of hospital beds aids pandemic fight, The Financial Times, 14 April.

18. Chen, Y. C., \& Gant, J. (2001). Transforming local e-government services: the use of application service providers. Government Information Quarterly, 18(4), 343-355.

19. Coad, A., Segarra, A., \& Teruel, M. (2016). Innovation and firm growth: does firm age play a role?. Research policy, 45(2), 387-400.

20. Conradie, P., \& Choenni, S. (2014). On the barriers for local government releasing open data. Government Information Quarterly, 31, S10-S17.

21. Cordella, A., \& Iannacci, F. (2010). Information systems in the public sector: The e-Government enactment framework. The Journal of Strategic Information Systems, 19(1), 52-66.

22. Cottam, H. (2018). Radical help: How we can remake the relationships between us and revolutionise the welfare state. Hachette UK.

23. Danailova, V.: Basic factors triggering the spelling reform in the Bulgarian Language. Crossing Boundaries in Culture and Communication, 5(2), 51-56 (2014)

24. Davison, R.M., Wagner, C., Ma, L.C.K. (2005). From Government to E-Government: A Transition Model. Information Technology \& People, 18 (3), 280-299. 
25. Dawes, S.S. (2008) The evolution and continuing challenges of egovernance. Public Adm Review. 68 (6), 82-102.

26. Demirbas, D., Hussain, J. G., \& Matlay, H. (2011). Owner-managers' perceptions of barriers to innovation: empirical evidence from Turkish SMEs. Journal of Small Business and Enterprise Development.

27. Drechsler, W., \& Kattel, R. (2020). Debate: The developed civil servant-providing agility and stability at the same time. Public Money \& Management, 40(8), 549-551.

28. Duerr, S., Holotiuk, F., Wagner, H. T., Beimborn, D., \& Weitzel, T. (2018, January). What is digital organizational culture? Insights from exploratory case studies. In Proceedings of the 51st Hawaii International Conference on System Sciences.

29. Dunleavy, P., Margetts, H., Bastow, S., \& Tinkler, J. (2006). New public management is dead-long live digital-era governance. Journal of public administration research and theory, 16(3), 467-494.

30. Dunleavy, P., Margetts, H., Bastow, S. and Tinkler, J. (2006), Digital Era Governance: IT Corporations, the State, and E-Government, Oxford University Press, Oxford.

31. D’Este, P., Iammarino, S., Savona, M., \& von Tunzelmann, N. (2012). What hampers innovation? Revealed barriers versus deterring barriers. Research policy, 41(2), 482-488.

32. Ebrahim, Z., \& Irani, Z. (2005). E-government adoption: architecture and barriers. Business Process Management Journal, 11(5), 589-611.

33. Effah, J., \& Nuhu, H. (2017). Institutional barriers to digitalization of government budgeting in developing countries: A case study of Ghana. The Electronic Journal of Information Systems in Developing Countries, 82(1), 1-17.

34. Eggers, W. D., \& Bellman, J. (2015). The journey to government's digital transformation. Deloitte. See https://www2. deloitte. com/uk/en/pages/public-sector/articles/the-journey-to-governmentsdigital-transformation. html (accessed 7 February 2018).

35. Eling, M., \& Lehmann, M. (2018). The impact of digitalization on the insurance value chain and the insurability of risks. The Geneva papers on risk and insurance-issues and practice, 43(3), 359-396

36. Falk, S., Römmele, A. \& Silverman, M. (2017a). The Promise of Digital Government. In Falk, S., Römmele, A. \& Silverman, M. (Eds.). Digital Government: Leveraging Innovation to Improve Public Sector Performance and Outcomes for Citizens (3-24). Cham: Springer

37. Fitzgerald, M., Kruschwitz, N., Bonnet, D. and Welch, M. (2014). Embracing digital technology: a new strategic imperative. MIT Sloan Management Review, 55(2), 1-12 
38. Fountain, J. E. (2004). Building the virtual state: Information technology and institutional change. Brookings Institution Press.

39. Gartner. (2016): IT Glossary, Digitalization. http://www.gartner.com/itglossary/digitalization. Sited 1st August, 2016.

40. Gaspar, V. , Lam, R. , \& Raissi, M. (2020). Fiscal policies to contain the damage from COVID-19. IMF Blog.

https://blogs.imf.org/2020/04/15/fiscal-policies-to-contain-thedamage-from-covid-19/. [Google Scholar]

41. Gebre-Mariam, M., \& Bygstad, B. (2019). Digitalization mechanisms of health management information systems in developing countries. Information and Organization, 29(1), 1-22.

42. Gerxhi, J. (2015). INNOVATIONS OF THE IMPLEMENTATION OF THE NEW LAW "FOR CIVIL SERVANTS\&quot; IN THE REPUBLIC OF ALBANIA, THE FUNCTION OF CONTEMPORARY PUBLIC ADMINISTRATION. European Scientific Journal, ESJ, 11(10). Retrieved from https://eujournal.org/index.php/esj/article/view/5433

43. Gil-Garcia, J. R., Helbig, N., \& Ojo, A. (2014). Being smart: Emerging technologies and innovation in the public sector. Government information quarterly, 31, I1-I8.

44. Gilbert, D., Balestrini, P., \& Littleboy, D. (2004). Barriers and benefits in the adoption of e-government. International Journal of Public Sector Management.

45. Gobble, M. M. (2018). Digitalization, digitization, and innovation. Research-Technology Management, 61(4), 56-59.

46. Grönlund, A. \& Horan, T.A. (2004). Introducing E-Gov: History, Definitions, and Issues. Communications of the Association for Information Systems, 15, 713-729

47. Hadjimanolis, A. (2003). The barriers approach to innovation. The international handbook on innovation.

48. Hagberg, J., Sundstrom, M., \& Egels-Zandén, N. (2016). The digitalization of retailing: an exploratory framework. International Journal of Retail \& Distribution Management.

49. Hartl, E., \& Hess, T. (2017). The role of cultural values for digital transformation: Insights from a Delphi study.

50. Heeks, R., \& Stanforth, C. (2007). Understanding e-Government project trajectories from an actor-network perspective. European Journal of Information Systems, 16(2), 165-177.

51. Heeks, R. (2006, July). Understanding and measuring eGovernment: international benchmarking studies. In UNDESA workshop, "E- 
Participation and E-Government: Understanding the Present and Creating the Future", Budapest, Hungary (pp. 27-28).

52. Helfat, C. E., \& Martin, J. A. (2015). Dynamic managerial capabilities: Review and assessment of managerial impact on strategic change. Journal of management, 41(5), 1281-1312.

53. Hendriks, C.J. (2013). Integrated Financial Management Information Systems: Guidelines for Effective Implementation by the Public Sector of South Africa: Original Research. South African Journal of Information Management, 15(1), 1-9

54. Hess, T., Matt, C., Benlian, A. and Wiesb€ock, F. (2016). Options for formulating a digital transformation strategy. MIS Quarterly Executive, 15(2), 123-139.

55. Janowski, T. (2015). Digital government evolution: From transformation to contextualization

56. Janssen, M., \& Estevez, E. (2013). Lean government and platformbased governance-Doing more with less. Government Information Quarterly, 30, S1-S8.

57. Janssen, M., \& Van Veenstra, A. F. (2005). Stages of growth in egovernment: An architectural approach. The electronic journal of $e$ government, 3(4), 193-200.

58. Janssen, M., Charalabidis, Y., \& Zuiderwijk, A. (2012). Benefits, adoption barriers and myths of open data and open government. Information systems management, 29(4), 258-268.

59. Jurisic, M., \& Kermek, D. (2011). Taxonomy of digital economy business models. In 2011 Proceedings of the 34th International Convention MIPRO.

60. Imgrund, F., Fischer, M., Janiesch, C., \& Winkelmann, A. (2018). Approaching digitalization with business process management. Proceedings of the MKWI, 1725-1736.

61. Imran, A. (2013). Individual Computer Usage Pattern and Perception amongst the Public Sector Officials in a Least Developed Country: A Descriptive Study. In Proceedings of 2013 International Conference on Information Resources Management (264-281). Red Hook: Curran Associates, Inc

62. Irani, Z., Love, P. E., \& Jones, S. (2008). Learning lessons from evaluating eGovernment: Reflective case experiences that support transformational government. The Journal of Strategic Information Systems, 17(2), 155-164.

63. Kalsi, N. S., \& Kiran, R. (2015). A strategic framework for good governance through e-governance optimization. Program.

64. Kamal, M. M., Weerakkody, V., \& Jones, S. (2009). The case of EAI in facilitating e-Government services in a Welsh 
authority. International Journal of Information Management, 29(2), 161-165.

65. Kaplan, B., Truex, D. P., Wastell, D., Wood-Harper, A. T., \& DeGross, J. I. (Eds.). (2006). Information systems research: Relevant theory and informed practice (Vol. 143). Springer.

66. Karamalis, P., \& Vasilopoulos, A. The digital transformation in public sector as a response to COVID-19 pandemic: The case of Greece.

67. Karasoy, H. A. (2018). Quality Management in Turkish Public Management: Challenges and Benefits. European Scientific Journal, ESJ, 14(5), 11. https://doi.org/10.19044/esj.2018.v14n5p11

68. Kattel, R., \& Mazzucato, M. (2018). Mission-oriented innovation policy and dynamic capabilities in the public sector.

69. Kim, S., Hyun Jeong Kim, H. J., \& Lee, H. (2009). An institutional analysis of an egovernment system for anti-corruption: The case of OPEN. Government Information Quarterly, 26(1), 42-50.

70. Kinnear, P. R., \& Gray, C. D. (2011). IBM SPSS Statistics 18 made simple. Psychology Press.

71. Klingler-Vidra, R., \& Wade, R. (2020). Science and technology policies and the middle-income trap: Lessons from Vietnam. The Journal of Development Studies, 56(4), 717-731.

72. Lam, W. (2005). Barriers to e-government integration. Journal of Enterprise Information Management.

73. Lazonick, W., \& Mazzucato, M. (2013). The risk-reward nexus in the innovation-inequality relationship: who takes the risks? Who gets the rewards?. Industrial and Corporate Change, 22(4), 1093-1128.

74. Legner, C., Eymann, T., Hess, T., Matt, C., Böhmann, T., Drews, P. and Ahlemann, F. (2017). Digitalization: opportunity and challenge for the business and information systems engineering community. Business \& information systems engineering, 59(4), 301308

75. Lewis, K. (2017) Blockchain: four use cases transforming business. IBM: Conferences. https://www.ibm.com/blogs/internet-of-things/iotblockchain-use-cases/ [Accessed 30 May 2018]

76. Luciano, E. M., Wiedenhöft, G. C., \& Santos, F. P. D. (2018, May). Promoting social participation through digital governance: identifying barriers in the Brazilian Public Administration. In Proceedings of the 19th Annual International Conference on Digital Government Research: Governance in the Data Age (pp. 1-9).

77. Luna-Reyes, L. F., \& Gil-Garcia, J. R. (2014). Digital government transformation and internet portals: The co-evolution of technology, organizations, and institutions. Government information quarterly, 31(4), 545-555. 
78. Machekhina, O. N. (2017). Digitalization of education as a trend of its modernization and reforming. Revista Espacios, 38(40).

79. Madrid-Guijarro, A., Garcia, D., \& Van Auken, H. (2009). Barriers to innovation among Spanish manufacturing SMEs. Journal of small business management, 47(4), 465-488.

80. Mahmood, M. (2018). Does Digital Transformation of Government Lead to Enhanced Citizens' Trust and Confidence in Government?. Springer.

81. Markus, M. L., \& Robey, D. (1988). Information technology and organizational change: Causal structure in theory and research. Management science, 34(5), 583-598.

82. Matt, C., Hess, T., \& Benlian, A. (2015). Digital transformation strategies. Business \& Information Systems Engineering, 57(5), 339343.

83. Maxwell, L., \& McCain, T. A. (1997). Gateway or gatekeeper: The implications of copyright and digitalization on education. Communication Education, 46(3), 141-157.

84. Mazzucato, M., \& Quaggiotto, G. (2020). The big failure of small government. Project syndicate, 19.

85. Mazzucato, M., \& Perez, C. (2015). Innovation as growth policy. The triple challenge for Europe: Economic development, climate change, and governance, 229.

86. Mazzucato, M., \& Kattel, R. (2020). COVID-19 and public-sector capacity. Oxford Review of Economic Policy,36(Supplement_1), S256-S269.

87. Millard, J. (2010), "Government 1.5 - Is the bottle half full or half empty?", European Journal of ePractice, Vol. 9, pp. 1-16.

88. Morakanyane, R., Grace, A. A., \& O'Reilly, P. (2017). Conceptualizing Digital Transformation in Business Organizations: A Systematic Review of Literature. Bled eConference, 21.

89. Morgeson III, F. V., VanAmburg, D., \& Mithas, S. (2011). Misplaced trust? Exploring the structure of the e-government-citizen trust relationship. Journal of Public Administration Research and Theory, 21(2), 257-283.

90. Osterwalder, A., \& Pigneur, Y. (2010). Business model generation: a handbook for visionaries, game changers, and challengers. John Wiley \& Sons.

91. Parasuraman, A., Valarie A. Zeithaml and Leonard L. Berry. (1988). "SERVQUAL: A Multi-Item Scale for Measuring Consumer Perceptions of Service Quality. Journal of Retailing, 64(Spring),1340. 
92. Park, H., \& Blenkinsopp, J. (2011). The roles of transparency and trust in the relationship between corruption and citizen satisfaction. International Review of Administrative Sciences, 77(2), 254-274.

93. Parviainen, P., Tihinen, M., Kääriäinen, J., \& Teppola, S. (2017). Tackling the digitalization challenge: how to benefit from digitalization in practice. International journal of information systems and project management, 5(1), 63-77.

94. Piatier, A., 1984. Barriers to Innovation. Frances Pinter, London

95. Picard, R. G. (2011). The economics and financing of media companies. Fordham Univ Press.

96. Piening, E. P. (2013). Dynamic capabilities in public organizations: A literature review and research agenda. Public management review, 15(2), 209-245.

97. Porter, M. E., \& Heppelmann, J. E. (2014). How smart, connected products are transforming competition. Harvard business review, 92(11), 64-88.

98. Ringenson, T., Höjer, M., Kramers, A., \& Viggedal, A. (2018). Digitalization and environmental aims in municipalities. Sustainability, 10(4), 1278.

99. Savoldelli, A., Codagnone, C., \& Misuraca, G. (2014). Understanding the e-government paradox: Learning from literature and practice on barriers to adoption. Government Information Quarterly, 31, S63-S71.

100. Saxena, A. (2005). E-Governance and good governance: the Indian context. The Indian Journal of Political Science, 313-328.

101. Schedler, K., \& Schmidt, B. (2004). Managing the egovernment organization. International Public Management Review, 5(1), $1-20$.

102. Schoonenboom, J., \& Johnson, R. B. (2017). How to construct a mixed methods research design. KZfSS Kölner Zeitschrift für Soziologie und Sozialpsychologie, 69(2), 107-131.

103. Schuppan, T. (2009). E-Government in developing countries: Experiences from sub-Saharan Africa. Government information quarterly, 26(1), 118-127.

104. Schwester, R. (2009). Examining the barriers to e-government adoption. Electronic Journal of e-government, 7(1).

105. Scott, M., DeLone, W., \& Golden, W. (2016). Measuring eGovernment success: a public value approach. European Journal of Information Systems, 25(3), 187-208.

106. Seng, W., Jackson, S. \& Philip, G. (2010), "Cultural issues in developing E-Government in Malaysia", Behaviour \& Information Technology, vol. 29, no. 4, pp. 423-432. 
107. Shotter, J., \& Jones, S. (2020). How Central and Eastern Europe Contained Coronavirus. Financial Times.

108. Simonet, D. (2011). The new public management theory and the reform of European health care systems: An international comparative perspective. International Journal of Public Administration, 34(12), 815-826.

109. Srai, J. S., \& Lorentz, H. (2019). Developing design principles for the digitalisation of purchasing and supply management. Journal of Purchasing and Supply Management, 25(1), 78-98.

110. Sun, Y., Yang, C., Shen, X. L., \& Wang, N. (2020). When digitalized customers meet digitalized services: A digitalized social cognitive perspective of omnichannel service usage. International Journal of Information Management, 54, 102200.

111. Teece, D. J. (2017). Dynamic capabilities and (digital) platform lifecycles. In Entrepreneurship, innovation, and platforms. Emerald publishing limited.

112. Temizel, M. (2015). TRANSFORMATION OF PUBLIC ADMINISTRATION AND THE APPROACH OF GOVERNANCE. European Scientific Journal, ESJ, 11(10). Retrieved from https://eujournal.org/index.php/esj/article/view/5911

113. Valenduc, G., \& Vendramin, P. (2017). Digitalisation, between disruption and evolution. Transfer: European Review of Labour and Research, 23(2), 121-134.

114. Van der Panne, G., Van Beers, C., \& Kleinknecht, A. (2003). Success and failure of innovation: a literature review. International Journal of Innovation Management, 7(03), 309-338.

115. Venkatesh, V., Thong, J. Y., \& Xu, X. (2012). Consumer acceptance and use of information technology: extending the unified theory of acceptance and use of technology. MIS quarterly, 157-178.

116. Warner, M. E. (2008). Reversing privatization, rebalancing government reform: Markets, deliberation and planning. Policy and society, 27(2), 163-174.

117. Weerakkody, V., Janssen, M., \& Dwivedi, Y. K. (2011). Transformational change and business process reengineering (BPR): Lessons from the British and Dutch public sector. Government Information Quarterly, 28(3), 320-328.

118. West, D. M. (2004). E-Government and the Transformation of Service Delivery and Citizen Attitudes. Public Administration Review 64(1), 15-27.

119. Westerman, G., and Bonnet, D. (2005). Revamping Your Business Through Digital Transformation. MIT Sloan Management Review, 1-6. https://doi.org/10.1108/10878571211209314 . 
120. Wing, L. (2005). Barriers to e-government integration. Journal of Enterprise Information Management, 18(5), 511-530.

121. Wiredu, G. O. (2012). Information systems innovation in public organisations: an institutional perspective. Information Technology \& People Valenduc, G., \& Vendramin, P. (2017). Digitalisation, between disruption and evolution. Transfer: European Review of Labour and Research, 23(2), 121-134.

122. Wu, S. M., Chen, T. C., Wu, Y. J., \& Lytras, M. (2018). Smart cities in Taiwan: A perspective on big data applications. Sustainability, 10(1), 106

123. Xanthopoulou, P., \& Karampelas, I. D. (2020). The Impact of Leadership on Employeesâ€ $€^{\mathrm{TM}}$ Loyalty and on Organizational Success: Do Transformational and Transactional Leadership Ensure Organizational and Work Commitment?. International Journal of Sciences, 9(10), 45-63.

124. Xanthopoulou, P. (2021). Innovation in Public Sector - A literature review on the impact of public sector digitalization on creating social value and organizational change, International Journal of Academic Management Science Research (IJAMSR), 5(1), January 2021

125. Xanthopoulou, P., \& Kefis, V. (2019). Public Organisations and Public Management in Greece: The Implementation of Private Management Tools in the Public Sector. International Journal of Sciences, 8(03), 45-54.

126. Xanthopoulou, P (2020). From e-Government to Public Value Creation. International Journal of Science and Research (IJSR), 9(3),927-933

127. Yong A G, Pearce (2013) A beginner's guide to factor analysis: Focusing on exploratory factor analysis. Tutorials in quantitative methods for psychology, 9(2), 79-94.

https://doi.org/10.20982/tqmp.09.2.p079

128. Yoo, Y. (2010). Digitalization and innovation. Institute of Innovation Research, Hitotsubashi University.

129. Zakareya, E., \& Zahir, I. (2005). E-government adoption: architecture and barriers. Business Process Management Journal, 11(5), 589-611.

130. Zhao, F. \& Khan, M.S. (2013). An Empirical Study of EGovernment Service Adoption: Culture and Behavioral Intention. International Journal of Public Administration, 36(10), 710-722 